\title{
Extruded Lumbar Disc Herniation with Spontaneous Reabsorption: Case Report and Review
}

\section{Reabsorção espontânea de hérnia discal lombar extrusa: relato de caso}

\author{
Carlos Eduardo da Silva ${ }^{1}$ Paulo Eduardo P. de Freitas ${ }^{2}$ Matheus V. Fernandes ${ }^{3}$ Matheus F. Gomes ${ }^{3}$ \\ Alex Spassim ${ }^{3}$ Ademar S. Mesquita jr ${ }^{3}$ Geniffer C. Cardoso ${ }^{3} \quad$ Gustavo S. Raupp ${ }^{3}$ Leonardo D. Olijnyk ${ }^{4}$ \\ ${ }^{1}$ Director, Neurosurgery and Skull Base Surgery Department, Hospital \\ Ernesto Dornelles, Porto Alegre, RS, Brazil \\ 2 Neurosurgeon, Neurosurgery and Skull Base Surgery Department, \\ Address for correspondence Carlos Eduardo da Silva, MD, Av. \\ Ipiranga, 1801, Azenha, Porto Alegre, RS, Brazil 90160-093 \\ Hospital Ernesto Dornelles, Porto Alegre, RS, Brazil \\ ${ }^{3}$ Medical Academic, Neurosurgery and Skull Base Surgery \\ Department, Hospital Ernesto Dornelles, Porto Alegre, RS, Brazil \\ ${ }^{4}$ Resident, Neurosurgery and Skull Base Surgery Department, \\ Hospital Ernesto Dornelles, Porto Alegre, RS, Brazil \\ Arq Bras Neurocir 2016;35:70-73. \\ (e-mail: dasilvacebr@yahoo.com.br).
}

\begin{abstract}
Disc herniation is a common condition in the population and has a direct impact on the

Keywords

- disc herniation

- spontaneous regression

- disc reabsorption

\section{Resumo} quality of life in patients, also causing functional limitations in the work place. Treatment protocols include conservative management and/or various surgical interventions. This paper reports on a case of symptomatic large extruded disc herniation, together with spontaneous clinical regression and total re-absorption. We show here conservative management, and a literature review of the main pathophysiological hypotheses for such an unusual evolution.

Hérnia discal é condição comum na população e tem impacto direto na qualidade de vida dos pacientes, assim como causa limitações funcionais em seu ambiente de

Palavras-chave

- hérnia discal

- regressão espontânea

- reabsorção discal trabalho. Protocolos de tratamento incluem manejo conservador e/ou diversos tipos de intervenção cirúrgica. Este artigo relata o caso de uma extensa hérnia extrusa sintomática, juntamente a sua regressão clínica espontânea e sua total reabsorção. Descrevemos também seu manejo conservador e uma revisão da literatura para a principal hipótese diagnóstica nesta evolução incomum.
\end{abstract}

\section{Introduction}

The herniated disc of the lumbar spine occurs more frequently in discs L4-L5 and L5-S1 transitionally. It is estimated that $2-3 \%$ of the population may be affected, with prevalence of

received

October 4, 2014

accepted

August 28, 2015
DOI http://dx.doi.org/ 10.1055/s-0035-1570496. ISSN 0103-5355.
$4.8 \%$ in men and $2.5 \%$ in women aged over 35 years. $^{1}$ All patients present changes in their performance at work due to pain, including the inability to work. ${ }^{2}$

Although surgical intervention for the treatment of this disease has existed for over 60 years, and the literature

Copyright $@ 2016$ by Thieme Publicações License terms Ltda, Rio de Janeiro, Brazil
(요 $\Theta \circledast$ 
describes many different techniques, conservative treatment is an alternative to surgery that may reverse the symptoms completely or partially, including partial reduction in the size of the hernia.

The authors present the case of a patient with a large extruded lumbar disc herniation and severe sciatic symptoms with spontaneous reabsorption of the disc and discuss the clinical aspects of this disease.

\section{Case Report}

A 31-year-old man, with morbid obesity, complains of intense lumbar and sciatic pain experienced for about two months and reports a worsening after physiotherapy. Magnetic resonance imaging (MRI) of the lumbar spine revealed a voluminous posterior median disc protrusion L5-S1, migrating cranial to the posterior portion of the L5 vertebral body (-Fig. 1). We considered surgical treatment, following a period of nutritional treatment. After 40 days, the patient had returned showing a weight loss of $29 \mathrm{~kg}$ and controlled pain (score 1 on a scale of 1 to 10 ), after using a nonsteroidal anti-inflammatory. A new MRI showed a spontaneous resolution of the herniated lumbar disc $\sim 5$ months after onset (-Figs. 1 and 2). In twelve months, the patient no longer complained of sciatic pain.

\section{Discussion}

Teplick and Haskin ${ }^{3}$ first documented spontaneous regression of a herniated disc after confirmation via a follow-up of computed tomography (CT) scans on 11 patients. Since then, reports of this phenomenon have surfaced randomly.

The literature describes cases of spontaneous resolution of the lumbar disc herniation in different clinical situations, including the presence of severe radiculopathy. ${ }^{4-8}$ Three mechanisms were proposed to explain this phenomenon.

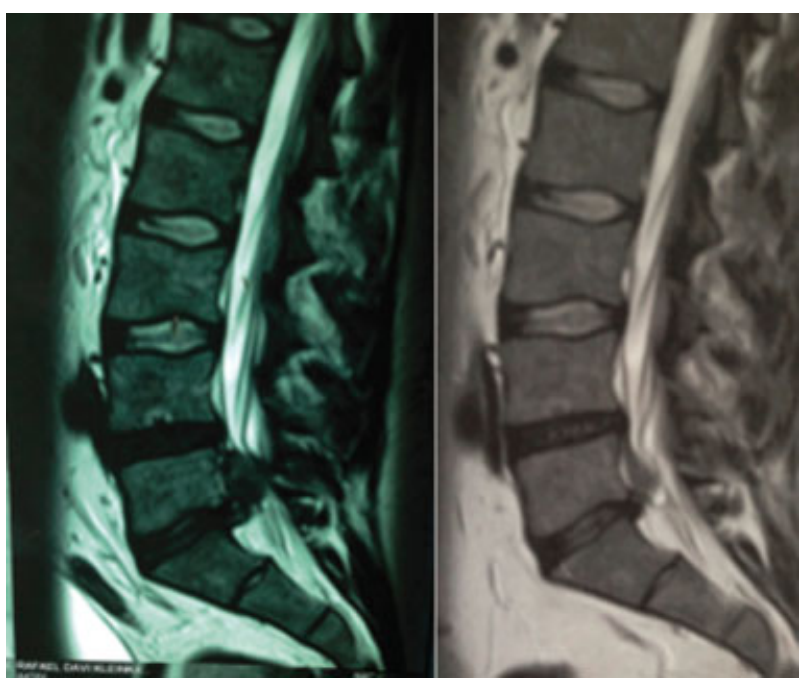

Fig. 1 Left: sagittal MRI with L5-S1 extruded disc herniation with upward dislocation; Right: sagittal MRI 5 months later with spontaneous disc herniation reabsorption.

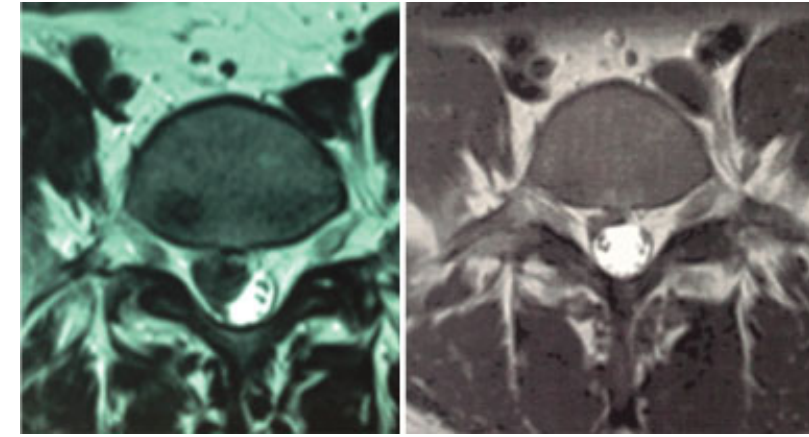

Fig. 2 Left: axial MRI with right disc herniation; Right: axial MRI presenting the spontaneous disc reabsorption.

The first defends that the herniated disc retracts, returning into the intervertebral space again. The second emphasizes that dehydration followed by shrinkage of the herniated disc occur. The last mechanism advocates enzymatic degradation and phagocytosis, due to an inflammatory reaction and neovascularization, which are responsible for such reabsorption. ${ }^{8,9}$ Hernias in the epidural space would be recognized by the immune system as foreign bodies, therefore, programming an inflammatory answer against trying to remove this invasive tissue. This reaction would lead to neovascularization, enzymatic degradation, and phagocytosis. ${ }^{10-15}$ Haroet et al, in a study designed with animal subjects, demonstrated that the induction of a condrocytic enzyme (metaloproteinase-3), through the macrophages, plays an essential role in the spontaneous re-absorption of the herniated tissue. ${ }^{13}$

The literature offers other pathologic processes. Burke et al ${ }^{16}$ stated that the intervertebral disc is able to produce cytokines (MCP-1 and IL-8), responsible for the macrophage chemotaxis and capillarization, which culminate in the synthesis of a granulation tissue that precedes the hernia reabsorption. Hirabayashi et $\mathrm{al}^{11}$ showed that epidural fat vessels infiltrate the herniated disc, and are followed by granulation tissue, with possible transformation into scar tissue. Carreon et al ${ }^{17}$ showed evidence of the different reactions between the fibrous annulus, which induce neovascularization and propitiate spontaneous reabsorption, including of the cartilage endplate. This presence reduces the neovascular response and prevents the degradation of the herniated tissue and reabsorption.

In a clinical study, Minamide et $\mathrm{al}^{18}$ demonstrated the presence of neovascularization and the increase in inflammatory cell numbers, which facilitated the reabsorption of the disc herniation in a group treated with fibroblastic growing factor.

The clinical impact of this spontaneous hernia resolution reflects a gradual change in management protocols, prioritizing the initial conservative treatment. Weber's study ${ }^{19}$ estimated that in one year of evolution, $25 \%$ of the patients initially managed conservatively would require surgery. In a larger study, ${ }^{20}$ only $15 \%$ of the patients managed conservatively needed the surgery within 3 months. This shows the importance of initially trying the conservative approach.

In a retrospective cohort study, Saal and Saal ${ }^{21}$ demonstrated that the conservative management of lumbar disc herniation 
with radiculopathy was considered efficacious in $90 \%$ of patients. In another study, Takada and Takahashi ${ }^{22}$ advocated that the average time for spontaneous regression of more than 50\% of the herniated mass varied from between 3 and 12 months.

In this context of initial conservative treatment, it is important to consider the predictive factors of hernia disc reabsorption known. Ahn et $\mathrm{al}^{23}$ elucidated that sequestrated disc herniation regresses faster than protuse herniation. Gadolinium contrasted MR studies demonstrated that sequestrated hernias tend to present rim enhancement, a sign of spontaneous regression or considerable mass reduction, in $75 \%$ of cases. ${ }^{24,25}$ Komori et $\mathrm{al}^{24}$ showed that the more pronounced the rim enhancement, the greater the tendency of regression.

Buttermann et $\mathrm{al}^{26}$ concluded that the larger the size of the herniated disc - specifically sequestrated and extruse types -, the greater the percentage of regression in size. They observed that patients who responded positively to the conservative management in the first six weeks exhibited faster hernia regression, with concomitant decrease in inflammation and pain.

Radicular pain can be explained either by the nervous compression by the hernia or by radicular inflammation and blood congestion. Radicular pain relief is justifiable in some cases before the reduction in size of the hernia, as a result of the improvement of secondary inflammatory responses. Pain usually reduces in 3-6 weeks, while hernia reabsorption takes 4-9 months. ${ }^{27}$

Rothoerl et $\mathrm{al}^{28}$ analyzed the time of the onset of symptoms in a surgically treated group, comparing with the postoperative outcomes, to define when to indicate surgery to obtain the best possible results. The conclusion was that the conservative treatment should be tried before 2 months, during which time the pain should have already presented a regression. After this period, surgery should be considered.

\section{Conclusion}

The possibility of spontaneous disc reabsorption should be considered in cases of lumbar disc herniation, even in large and extruded ones. In cases where there are no emergency criteria for radicular decompression, conservative management should be a reasonable option for the initial treatment of these patients.

\section{References}

1 Vialle LRV, Emiliano N, Henao JES, Giraldo G. Hérnia discal lombar. Rev Bras Ortop 2010;45(1):17-22

2 Carvalho MEI, Carvalho Junior RM, Carvalho RA, Paula Junior AR. Limitação funcional em pacientes com hérnia discal lombar e o impacto na vida laboral. Terapia Manual 2010;38(8): 320-324

3 Teplick JG, Haskin ME. Spontaneous regression of herniated nucleus pulposus. AJR Am J Roentgenol 1985;145(2):371-375

4 Sabuncuoğlu H, Ozdoğan S, Timurkaynak E. Spontaneous regression of extruded lumbar disc herniation: report of two illustrative case and review of the literature. Turk Neurosurg 2008;18(4): 392-396

5 Ellenberg M, Reina N, Ross M, Chodoroff G, Honet JC, Gross N. Regression of herniated nucleus pulposus: two patients with lumbar radiculopathy. Arch Phys Med Rehabil 1989;70(12):842-844

6 Fager CA. Observations on spontaneous recovery from intervertebral disc herniation. Surg Neurol 1994;42(4):282-286

7 Komori H, Shinomiya K, Nakai O, Yamaura I, Takeda S, Furuya K. The natural history of herniated nucleus pulposus with radiculopathy. Spine 1996;21(2):225-229

8 Slavin KV, Raja A, Thornton J, Wagner FC Jr. Spontaneous regression of a large lumbar disc herniation: report of an illustrative case. Surg Neurol 2001;56(5):333-336, discussion 337

9 Guinto FC Jr, Hashim H, Stumer M. CT demonstration of disk regression after conservative therapy. AJNR Am J Neuroradiol 1984;5(5):632-633

10 Doita M, Kanatani T, Harada T, Mizuno K. Immunohistologic study of the ruptured intervertebral disc of the lumbar spine. Spine 1996;21(2):235-241

11 Hirabayashi S, Kumano K, Tsuiki T, Eguchi M, Ikeda S. A dorsally displaced free fragment of lumbar disc herniation and its interesting histologic findings. A case report. Spine 1990;15(11): 1231-1233

12 Ito T, Yamada M, Ikuta F, et al. Histologic evidence of absorption of sequestration-type herniated disc. Spine 1996;21(2):230-234

13 Haro H, Crawford HC, Fingleton B, et al. Matrix metalloproteinase3-dependent generation of a macrophage chemoattractant in a model of herniated disc resorption. J Clin Invest 2000;105(2): 133-141

14 Doita M, Kanatani T, Ozaki T, Matsui N, Kurosaka M, Yoshiya S. Influence of macrophage infiltration of herniated disc tissue on the production of matrix metalloproteinases leading to disc resorption. Spine 2001;26(14):1522-1527

15 Henmi T, Sairyo K, Nakano S, et al. Natural history of extruded lumbar intervertebral disc herniation. J Med Invest 2002;49(1-2):40-43

16 Burke JG, Watson RW, McCormack D, Dowling FE, Walsh MG, Fitzpatrick JM. Spontaneous production of monocyte chemoattractant protein-1 and interleukin- 8 by the human lumbar intervertebral disc. Spine 2002;27(13):1402-1407

17 Carreon LY, Ito T, Yamada M, Uchiyama S, Takahashi HE. Neovascularization induced by annulus and its inhibition by cartilage endplate. Its role in disc absorption. Spine 1997;22(13):1429-1434, discussion 1446-1447

18 Minamide A, Hashizume H, Yoshida M, Kawakami M, Hayashi N, Tamaki T. Effects of basic fibroblast growth factor on spontaneous resorption of herniated intervertebral discs. An experimental study in the rabbit. Spine 1999;24(10):940-945

19 Weber H. Lumbar disc herniation. A controlled, prospective study with ten years of observation. Spine 1983;8(2):131-140

20 Atlas SJ, Keller RB, Chang Y, Deyo RA, Singer DE. Surgical and nonsurgical management of sciatica secondary to a lumbar disc herniation: five-year outcomes from the Maine Lumbar Spine Study. Spine 2001;26(10):1179-1187

21 Saal JA, Saal JS. Nonoperative treatment of herniated lumbar intervertebral disc with radiculopathy. An outcome study. Spine 1989;14(4):431-437

22 Takada E, Takahashi M, Shimada K. Natural history of lumbar disc hernia with radicular leg pain: Spontaneous MRI changes of the herniated mass and correlation with clinical outcome. J Orthop Surg (Hong Kong) 2001;9(1):1-7

23 Ahn SH, Ahn MW, Byun WM. Effect of the transligamentous extension of lumbar disc herniations on their regression and the clinical outcome of sciatica. Spine 2000;25(4):475-480

24 Komori H, Okawa A, Haro H, Muneta T, Yamamoto H, Shinomiya K. Contrast-enhanced magnetic resonance imaging in conservative management of lumbar disc herniation. Spine 1998; 23(1):67-73 
25 Yamashita K, Hiroshima K, Kurata A. Gadolinium-DTPA-enhanced magnetic resonance imaging of a sequestered lumbar intervertebral disc and its correlation with pathologic findings. Spine 1994;19(4):479-482

26 Buttermann GR. Lumbar disc herniation regression after successful epidural steroid injection. J Spinal Disord Tech 2002;15(6):469-476
27 Orief T, Orz Y, Attia W, Almusrea K. Spontaneous resorption of sequestrated intervertebral disc herniation. World Neurosurg 2012;77(1):146-152

28 Rothoerl RD, Woertgen C, Brawanski A. When should conservative treatment for lumbar disc herniation be ceased and surgery considered? Neurosurg Rev 2002;25(3):162-165 